\title{
MUSLIMS FROM AL-ANDALUS IN THE MADRASAS OF LATE FĀṬIMID AND AIYŪBID EGYPT
}

\author{
Gary LEISER \\ Vacaville, California
}

Medieval Arabic sources record the first trips by Muslims from al-Andalus (Spain) to the Islamic East and back around the middle of the second/eighth century. This travel increased in intensity during the following two centuries and then gradually declined. By the end of the sixth/twelfth century, it had slowed to a trickle. There were many reasons for this travel, above all the pilgrimage to Mecca, trade, and the pursuit of knowledge. Among these major reasons, the last, which meant chiefly the study of the religious sciences, stands out as the most important. Indeed, this type of travel to the East was critical for the Islamization of al-Andalus. ${ }^{1}$ The very term for travel, rihla, had a technical meaning, namely, a journey to the Islamic East for the sake of learning. ${ }^{2}$ Although most Andalusi Muslims who set out for the East appear to have returned to their homeland, some were emigrants. Their preferred places of settlement, often after traveling throughout much of the Middle East, were Mecca and Alexandria. ${ }^{3}$ These emigrants usually earned a living by teaching, thus putting to good use the fruits

\footnotetext{
${ }^{1}$ This phenomenon has been described in excellent fashion by Michael Lenker in his doctoral dissertation, "The Importance of the Rihla for the Islamization of Spain", University of Pennsylvania, 1982. Lenker, who concentrates on the second-sixth/eighth-twelfth centuries, shows that learning in alAndalus was thoroughly Islamic thanks to the rihla and completely refutes Henri Pérès' claim in $L a$ Poésie andalouse en arabe classique au Xf siècle, Paris, 1953, that the secular tendencies in al-Andalus were caused by the humanistic rather than the religious nature of Andalusĩ education. On the nonreligious sciences that were studied in the East, see A. Dū N-Nūn TTāhā, «Importance des voyages scientifiques entre l'Orient et l'Andalus", ROMM, 40 (1985), 39-44. For some general remarks on travel to the East after the sixth/twelfth century, see Rachel Arie, «Notes sur les échanges culturels entre alAndalus et l'orient musulman au bas moyen agen, in Adel Sidarus ed., Islão e arabismo na península ibérica, Evora, 1986, 133-146. For a very general overview with no documentation, see Gamal Eldin Elshayyal, «The Cultural Relations between Alexandria and the Islamic West in al-Andalus and Morocco", Revista del Instituto de Estudios Islámicos en Madrid, 16 (1971), 61-69. For a broader view of rihla within the Muslim world, see Sam Gellens, «The Search for Knowledge in Medieval Muslim Societies: A Comparative Approach", in Dale Eickelman and James Piscatori eds., Muslim Travelers: Pilgrimage, Migration and the Religious Imagination, London, 1990, 50-65.

${ }^{2}$ It is worthy of note that the two most famous works by Andalusis describing travel to the East, Rihlat Ibn Jubair and Rihlat Ibn Battuitata, are always translated, imprecisely, as The Travels of Ibn Jubair and The Travels of Ibn Batthīa. They did not travel aimlessly, but in order to acquire knowledge.

${ }^{3}$ Luis Molina has made a quantitative study of the places visited by the Andalusīs found in Ibn alFaradị's (d. 403/1013) Ta'rikh 'ulamä' al-Andalus. See his "Lugares de destino de los viajeros andalusíes en el Ta'rīj de Ibn al-Faradīin, Estudios Onomástico-Biográficos de al-Andalus, 1 (1988), 585-610. Manuela Marín has studied the travels of one Andalusī in particular, «El viaje a Oriente de Abū Marwān al-Bāŷī (m. 635/1237)», same journal, 6 (1994), 273-304.
} 
of their rihlas. Consequently, when madrasas, or Islamic colleges of law, first appeared in Alexandria in the late Fạtimid period (495-567/1101-1171) and then spread throughout Egypt during the Aiyūbid era (567-648/1171-1250), Andalusī Muslims were in a position to play a noteworthy role in their development. This paper will describe that role. ${ }^{4}$ The travel of North African Muslims to Egypt generally followed the same pattern as that of the Andalusis. They will be included in this study as well, although their number was much smaller.

\section{BACKGROUND}

The rudiments of the Islamic sciences were taught in Egypt from the moment the Arabs conquered it in 20/641, but more than a century passed before any of the law schools (madhhabs) firmly took root there. The somewhat conservative Mālikī madhhab was the first to do so. Al-Maqrīzì says it was introduced by one 'Abd al-Rahīm b. Khālid b. Yazīd b. Yaḥyā who died in 163/779-780. Because of the zeal of its adherents, it quickly spread throughout Muslim Egypt and was never challenged by the less conservative Hanafi madhhab, which was the only other Sunnī school then in existence. Indeed, al-Maqrīzī goes so far as to say that the madhhab of Abū Hanīfa was not even known in Egypt at that time. The Mālikīs were unrivaled until the Imām al-Shāfi'i himself went to Egypt in 198/814. He studied and taught in Fustâat until his death in 204/820 and then was buried in the Qarāfa Cemetery nearby. His teachings became the basis of the second major law school in Egypt, which was named after him, and his followers eventually became the chief competitors of the Mãlikīs. Meanwhile, the Hanafīs had established a presence, but remained relatively insignificant. ${ }^{5}$ It is reported, for example, that in 326/938 the Mālikīs and Shāfi 'īs each had fifteen circles of students in the Mosque of 'Amr in Fustạt while the Hianafis had only three. ${ }^{6}$ There were also a few Shî' 'is about, but they were of no consequence. ${ }^{7}$

In 358/969 the Fậtimids invaded Egypt and introduced major changes. Most importantly, they replaced Sunnī Islam with the Ismā'ilī version of Shī 'ism as the official state religion. Sunnism was technically forbidden and Shī 'ism was encouraged. Nevertheless, the great majority of Egyptian Muslims remained

\footnotetext{
${ }^{4}$ Most of the data in this study are extracted from my dissertation, "The Restoration of Sunnism in Egypt: Madrasas and Mudarrisūn 495-647/1101-1249», University of Pennsylvania, 1976.

${ }^{5}$ Al-Maqrīzi, al-Khitat, Bulaq, Egypt, 1270/1853, vol. 2, 334.

6 Adam Mez, The Renaissance of Islam, trans. from German by Khuda Bakhsh and D. S. Margoliouth, 1937, rpt. Beirut, 1973, 214.

${ }^{7}$ Al-Khitat, vol. 2, 334.
} 
Sunnīs. One reason for this was that the Fạtimids were more interested in spreading their ideology abroad than at home where proselytizing was sporadic and usually halfhearted. Still, if the Fậtimids did not convert the Sunnīs of Egypt, they at least tried to control them by repression or, it seems, playing one school against another. Al-Maqrīzi, again, states that in 381/991-992 a man was beaten because a copy of Mālik's great book of law, the Muwatta', was found in his possession. ${ }^{8}$ Around the same time, the well-known geographer al-Muqaddasī (fl. fourth/tenth century) passed through Egypt and reported that a Shāfi ${ }^{\prime} \bar{i}$ was the imām (prayer leader) of the Mosque of Ibn Țulūn, which was essentially in Fusțāt, and that until that time all the imāms had been Māilīis. In fact, most of the jurists or fuqahä' were Mālikīs. ${ }^{9}$ Perhaps the Fătimids had appointed the Shāfi 'î imām for political reasons. Al-Muqaddasī also mentions that there were Hanbalīs in Fustăt. ${ }^{10}$ As for the Hanafīs, the Fạtimids especially disliked them because they were of the same madhhab as the "Abbāsids, their archenemies in Baghdad. ${ }^{11}$ On the whole, the well-being of the Sunnis in Egypt depended on the authority, power, or whim of the caliphs and their viziers. State policy could be extremely repressive, such as during the reign of the notorious caliph al-Hiākim (especially between 390-411/1000-1021), or very relaxed, such as during the vizierate of alAfḍal (487-515/1094-1121). ${ }^{12}$

During the Fạtimid period, the number of Shāfi 'īs seems to have increased somewhat at the expense of the Mālikīs. Apart from this, the strength of each Sunni madhhab appears to have remained at approximately the same proportion as before the Fậtimid conquest. The Mālikiss and Shāfi 'îs were the most important groups while the Hanafis and then the Hanbalis lagged far behind. For the sixth/twelfth century, and to some extent earlier, we can get a rough idea of the relative strength and vitality of each school from al-Suyựtī's Hisn al-muhädara. ${ }^{13}$ Although he is late (d. 911/1505) and had a pro-Shāfi 'ì bias, the author culled

\footnotetext{
${ }^{8}$ Ibid., vol. 2, 341

${ }^{9}$ Alısan al-taqāsim, ed. J. de Goeje, $2^{\text {nd }}$ ed., Leiden, 1906, 203-204; Mez, Renaissance, 214.

${ }^{10}$ Ahsan al-taqāsim, 202. On the first appearance of Hanbalīs in Egypt, see Leiser, «Hanbalism in Egypt before the Mamlûks", Studia Islamica, 54 (1981), 155-181.

${ }^{11}$ Muhammad Jamāl al-Dīn Surūr, al-Dawla al-fătimiyya fï Mișr, Cairo, 1965-1966, 85.

${ }^{12} \mathrm{Ibid} ., 79-85$. H̦asan Ibrähìm Hasan, Ta'rikh al-dawla al-fätimiyya, $2^{\text {nd }}$ ed., Cairo, 1958, 218-225, 621-624; Marius Canard, «Fātimids», $E I^{2}$, vol. 2, 859. Ibn al-Qifțī, Inbăh al-ruwät, ed. Muhammad Abū 'l-Faḍl Ibrähīm, Cairo, 1369-1393/1950-1973, vol. 2, 73, apparently referring to the last years of Fạtimid rule, says, for example, that the people of Qift in Upper Egypt were Sunnīs who openly displayed their beliefs. The Fătimids knew of this but did not bother them. So far, there has been no comprehensive study of the Sunni madhhabs in Fătimid Egypt. Cf. Yaacov Lev, «The Fatimid Imposition of Ismā'ilism on Egypt (358-386/969-996)», ZDMG, 138 (1988), 313-325, and idem, State \& Society in Fätimid Egypt, Leiden, 1991, chapter 8.

${ }^{13}$ Ed. Muhammad Abū 'l-Faḍl lbrāhīm, Cairo, 1387/1967-1968, vol. 1, 398-484
} 
material from many earlier works and drew up a list of the most famous fuqah $\bar{a}$ of each Sunnī madhhab in Egypt. Here we find the following:

\begin{tabular}{l|c|c}
\hline \hline & $\begin{array}{c}\text { NUMBER FROM EACH } \\
\text { MADHHAB }\end{array}$ & $\begin{array}{c}\text { NUMBER WHO DIED } \\
\text { BEFORE 600/1203-1204 }\end{array}$ \\
\hline Shāfi‘ī & 202 & 59 \\
\hline Mālikī & 92 & 53 \\
\hline Ḥanafì & 58 & 10 \\
\hline Ḥanbalì & 21 & 0 \\
\hline
\end{tabular}

Al-Suyūtî̀'s list is more weighted, naturally, as he approaches his own time and, to repeat, he does not include the jurists who did not become famous. Still, it is clear that Egypt was predominantly Mālikī and Shāfi 'ī territory.

With respect to the last years of Fātimid rule, the evidence at hand indicates that the Sunnis endured little, if any, oppression. In fact, they seem to have thrived and to have had at least as much freedom as any other tolerated religious community. This condition was facilitated, no doubt, by a declining caliphate and the many non-Ismāîlìs - Sunnīs and Imāmīs - who served as vizier. The Sunnī viziers could more or less minimize Shí ${ }^{\top} \overline{1}$ interference in their affairs, while the Imāmī viziers had their own rivalry with the Ismā'ilis and were unconcerned with the Sunnīs. Kutaifāt, al-Afḍal's son and an Imāmī who served briefly as vizier from 524/1130 to 526/1131, appointed for the first time four chief judges in

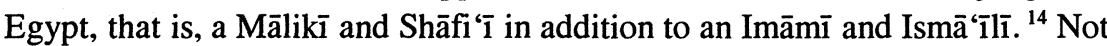
long afterward, in 532/1137-1138, the Sunnī vizier Riḍ̂ān b. al-Walakhshī was

${ }^{14}$ See above all Samuel Stern, «The Succession to the Fatimid Imam al-Āmir, the Claims of the Later Fatimids to the Imamate, and the Rise of Tayyibī Ismailism», Oriens, 4 (1951), 193-207, and «alAfḍal... Kutaifāt’, $E I^{2}$, vol. 1, 216, to which add Ibn Zāâir, Akhbär al-duwal al-munqati 'a, ed. André

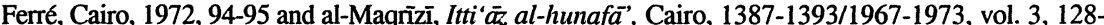
$130,137-142$. In Stern's two articles, he says on pp. 206 and 216, respectively, that the Sunni judges were a Shāfi' 1 and a Hanafí. This is a partial oversight because Ibn Muyassar, whom Stern cites, says in fact that they were a Shāfi'i and a Mālikī, as does al-Maqrīzī, Itti 'äz̆, vol. 3, 142. As we have noted above, Egypt was overwhelmingly Mālikī and Shāfi 'ī, so there would have been no reason to appoint a Hanafĩ chief judge. Now see Adel Allouche, «The Establishment of Four Chief Judgeships in Fătimid Egypts, JAOS, 105 (1985), 317-320. For the decline of the Fătimid ideology and missionary work, see Hussain Akberali Ladak, «The Fătimid Caliphate and the Ismā‘īlī Da'wa - From the Appointment of Musta 'li to the Suppression of the Dynasty", Dissertation, Univ. of London, 1971. 
the first government official to found a madrasa in Egypt. It was located in Alexandria for the Mālikīs.

The Sunnīs, therefore, remained the great majority in Egypt throughout the Fậtimid period. Apart from politics, one important reason for this was that they were strengthened by a continuous stream of adherents from abroad. In particular, Egypt lay on the pilgrimage route to Mecca for the Muslims of al-Andalus and North Africa, collectively known here as Maghribīs. And when the Hilālian invasion put an end to Qairawān as a great center of Islamic civilization in 449/1057, Egypt, above all Alexandria, became the only major center of learning for these Muslims in the vast area between al-Andalus and heartlands of the Islamic East. The biographical dictionaries of Andalusīs are especially replete with people who went to Mecca or more distant Muslim cities via Egypt. Virtually all Mālikīs, many stayed in Egypt for many years or permanently. Indeed, one of the reasons given for Riḍwān's decision to establish a madrasa in Alexandria was that it would serve as a rest house and hostel for pilgrims and travelers. It also served, of course, as a meeting place and center of Mālikī law and thus strengthened the Mālikī community.

Sunnīs, mainly Shāfi 'îs and H̦anafīs, also went to Egypt from the East. Some were pilgrims from Syria and beyond who preferred to take a boat to Alexandria rather than go directly overland. But travelers of other kinds arrived as well. The coming of the Crusades, however, made the land and sea routes between Egypt and Syria hazardous, so that from the reign of al-Āmir (495-525/1094-1101) to that of al-`Ādid (555-567/1160-1171), communications with the East were often partially or wholly interrupted.

In contrast to this, the movement of Andalusīs to Egypt during this time was generally unhindered. Consequently, as we shall see, they were able to play a significant role in the early development of madrasas in Egypt and to some degree in the subsequent pedagogical function of these institutions. Their activity appears to have been in proportion to the intensity of the rihla, which, as noted, declined in the sixth/twelfth century.

\section{MUSLIMS FROM AL-ANDALUS AND THE BEGINNING OF THE MADRASA MOVEMENT IN EGYPT}

The first de facto madrasa in Egypt may have been the work of Abū Bakr Muḥammad b. al-Walīd b. Muḥammad b. Khalaf b. Sulaimān b. Aiyūb al-Fihrī 
al-Ṭurtūshī, also known as Ibn Abī Randaqa ${ }^{15}$ He was born around 451/1059 in Tortosa. He spent his early life there and then traveled about al-Andalus until he became a student of the Mālikī theologian and judge (qāậl) Abū 'l-Walīd al-Bājī (d. 474/1081) in Saragossa. After completing his studies with him and receiving an $i j a z a$ (authorization to teach certain books), he went to the East and made the pilgrimage.

According to Ibn Khallikān, al-Ṭurtūshī departed al-Andalus in 476/10831084. ${ }^{16} \mathrm{He}$ next appears in Mecca where one of his classmates under al-Bājī, Abū 'Alī al-Husain b. Muhammad b. Firrū (or Firruh [?], which derived from the Latin word for iron) al-Șadafi studied from him the Sunan (one of the six canonical works on hadīth [traditions] accepted by Sunnīs) of Abū Dāwūd according to ('an) al-Tustari. ${ }^{17}$ From there al-Ṭurtūshi proceeded to Baghdad where the great vizier Niz̄ām al-Mulk was in power. In his Siräj al-mulük, al-Ṭurtūshī praises the vizier and takes special notice of the educational and religious facilities that he constructed, namely, a där al-'ilm (library), madrasas, and ribäts (fortified Șūfī retreats). ${ }^{18} \mathrm{Al}-$ T urtüshī attributes to Nizām a resurgence in learning throughout the realm.

He naturally singles out the Nizāmiyya Madrasa. ${ }^{19}$ In fact, although he was a Mālikī and this was a Shāfi 'ī institution, he certainly studied there. Baghdad then had a relatively insignificant Mālikī community and no Mālikī madrasas. He therefore studied fiqh (jurisprudence) in that city from others, especially Shāfi 'īs.

\footnotetext{
${ }^{15} \mathrm{He}$ is frequently mentioned in the sources and deserves to be extensively studied. A list of the major works in which he appears can be found in Jamal al-Dīn al-Shayyāl, $A$ 'läm al-Iskandariyya $f f^{\prime} l$ ' 'assr al-islānü, Cairo, 1965, 114 (al-Shayyäl's reference to M. Ben Cheneb should be corrected to read, "Études sur les personnages mentionnés dans l' Ijāza du cheikh 'Abd al-Qādir al-Fāsyn, Actes du XIV" Congrès International des Orientalistes, 1905, vol. 3, pt. 2, 335-336 [1906-1908; rpt. Nendeln/ Leichtenstein, 1968]), to which add the references in Ibn Khallikān, Wafayāt al-a yā̄n, ed. Thsān 'Abbās, Beirut, 1968-1972, vol. 4, p. 262, vol. 7, 329; al-Șafadī, al-Wäfi bi-'l-wafayät, ed. Hellmut Ritter et al., Istanbul, 1931, vol. 5, 175, n. 1; s. v. in al-Silafi's Mu'jam al-safar, 'Ārif Hikmet (Medina) MS. 176, hadżh (Institute of Arabic Manuscripts in Cairo, microfilm nr. 1234, $t a$ ' rikh), now published in Beirut, 1993; GAL, vol. 1, p. 459 and Supplement, vol. 1, 829-830; Ben Cheneb, ulbn Abī Randaḳa", $E I^{1}$. Although useful, al-Shayyāl's chapter on him in $A^{\prime} l a \bar{m}, 50-100$, is inadequately documented. $C f$. Ét. Quatremère, «Notes de M. Étienne Quatremère sur divers sujects orientaux", JA, ser. 5, 17 (1861), 147-154. The most recent work related to al-Turtūshì is Maribel Fierro, ed. and Spanish trans. of his Kitäb al-Hawädith wa 'l-bida', Madrid, 1993.

${ }^{16}$ Wafayät, vol. 4, 262; al-Maqqarī, Nafh al-tıb min ghusn al-Andalus al-ratıb, ed. R. Dozy et al. as Analectes sur l'histoire et la littérature des arabes d'Espagne, 1855-1861, rpt. Amsterdam, 1967, vol. 1, 518.

${ }^{17}$ Yãqūt, Mu'jam al-buldān, ed. F. Wüstenfeld, Leipzig, 1866-1873, vol. 3, 530.

${ }^{18}$ Cairo, 1306, 104, new ed. Muhammad Fathī Abū Bakr, Cairo, 1994, and al-Shayyāl, A 'läm, 58. The Siräj has been translated into Spanish by Maximiliano Alarcón as Lámpara de los príncipes por Abubéquer de Tortosa, Madrid, 1930-1931.

${ }^{19}$ Siräj, 104-105; al-Shayyāl, A'läm, 60.
} 
Among them were Abū Bakr al-Shāsh $\bar{i}^{20}$ and $\mathrm{Abū} \mathrm{Sa}{ }^{\mathrm{d}} \mathrm{d}$ al-Mutawallī. ${ }^{21}$ The latter was the mudarris (professor) in the Nizāmiyya twice between 476/1083 and 478/1086 when he died. ${ }^{22}$ The former, one of the leading Shăfi ${ }^{i} \bar{i}$ scholars in Baghdad, received the professorship in the Nizāmiyya in 504/1111. ${ }^{23}$ Before that, he taught in a madrasa named after himself and then in the Tăjiyya Madrasa starting in 482/1089. ${ }^{24}$ Thus, al-Ṭurtūshĩ studied in the Nizāmiyya and probably other madrasas in Baghdad. ${ }^{25}$

From Baghdad he went to Bașra. Later he turned up in Syria and taught figh in Jerusalem. He went on to Antioch and then apparently went by sea to Egypt, reaching al-Rashīd (Rosetta) around 490/1097. His reputation had preceded him. Consequently, the judge of Alexandria, al-Makin b. Hadīd, accompanied by a group of fellow townsmen, met him in al-Rashìd and encouraged him to settle in Alexandria. ${ }^{26}$ Therefore, he moved to that city where he married a woman of wealth. She provided him with a large house $(d \bar{a} r)$ of two stories. The upper floor was their living quarters while al-Turtūshī used the reception hall $\left(q \bar{a}^{\prime} a\right)$ and the rest of the lower floor as a de facto madrasa where he taught figh ${ }^{27}$ This «madrasa» was large enough to lodge at least some students, for we have the testimony of someone who stayed there many nights. ${ }^{28}$ Nothing else is known of this "madrasa" except that it had a professional mu'adhdhin (one who made the call to prayer). ${ }^{29}$

In their biographies of al-Țurtūshī, both al-Ḍabbī and Ibn Farḥun, who used different sources, say that he created a madrasa in Alexandria. Presumably, they mean this dār. After al-Turtūshī's death, however, there is no echo of the existence of this madrasa in any source. This suggests that it was not an endowed institution. Nevertheless, al-Țurtūshī seems to have set himself up in his dār as if it were a madrasa, inspired no doubt by his experience in Baghdad. His där was certainly an independent Sunnī school, supported by private funds, with a single teaching

${ }^{20}$ Abū Bakr Muhammad b. Aḥmad al-Qaffāl al-Shāshī (d. 507/1114), GAL, vol. 1, 390-391, Supplement, vol. 1, 674 .

${ }^{21}$ Abū Sa‘d 'Abd al-Raḥmān b. Ma' mūn b. 'Alī b. Ibrāhīm al-Mutawallī (d. 478/1086), al-Subkī, Țabaqā̃ al-shăfi 'iyya al-kubrā, eds. Maḥmūd Muhammad al-Ṭanāhī and 'Abd al-Fattāḥ al-Ḥilū, Cairo, 1383-1396/1964-1976, vol. 5, 106-107.

${ }^{22}$ Makdisi, G., «Muslim Institutions of Learning in Eleventh-Century Baghdad", BSOAS, 24 (1961), 38-39.

${ }^{23} \mathrm{Ibid} ., 41$.

${ }^{24}$ Ibid., 25-26.

${ }^{25} \mathrm{Al}-\mathrm{D}$ abbī (d. 599/1203) says he studied hladith in the 'Ādiliyya Madrasa, which I have not been able to identify, Bughyat al-multamis fi ta'rikh rijal ahl al-Andalus, Cairo, 1968, 135.

${ }^{26}$ Ibid., 135-137.

${ }^{27}$ Ibn Farhūn, al-Dibäj al-mudhhab, Cairo, 1351/1932, 277. Cf. al-Ḍabbī, Bughya, 137.

${ }^{28}$ Al-Dabbī, Bughya, 137.

${ }^{29}$ Al-Silafî, Mu 'jam, s. v. Abū 'l-Qāsim Najā b. 'Alī b. al-Ḥasan al-Ramlī. 
position mainly for figh, and providing lodging for students. It was only one step away from a fully endowed traditional madrasa. Indeed, as we shall see, it laid the ground work in Egypt for the traditional madrasas that soon began to appear.

Al-T urtūshī attracted a large number of students, especially Andalusīs who found his madrasa a welcome place to study or visit on the way to Mecca or beyond. ${ }^{30} \mathrm{He}$ is described in an anecdote as walking in a garden with 360 students and admirers. ${ }^{31}$ His popularity, combined with his self-centeredness, perhaps contributed to the growth of ill-will between him and Ibn Hadīd for they had a falling-out. This in turn brought him in conflict with the vizier al-Afdal, whom he did not hesitate to lecture about what was religiously permissible. ${ }^{32}$ After al-Afdal was killed, al-Turtūshī composed his Siräj which he then presented in Cairo to the new vizier al-Ma'mūn b. al-Batāà iṇī, an Imāmī, as a kind of Fürstenspiegel. ${ }^{33}$ As mentioned, this work includes the author's account of his visit to Baghdad and his respect for the institutions of learning in that city. Al-Maqrīzi states that alTiurtūshī and the vizier reached an agreement on the rules of inheritance according to which an estate would be apportioned in accordance with the rules of the madhhab of the deceased. This suggests that the Ismā'ilis had been interfering in Sunnī affairs. Al-Ma'mūn also agreed to compensate for funds improperly taken from orphans during al-Afdal's vizierate. A sijill (edict) with the signatures of the vizier and caliph was sent to all the judges of the country ordering them to abide by this agreement. Finally, al-Țurtūshī asked the vizier to build a masjid (neighborhood mosque) in Alexandria near the sea and he agreed. ${ }^{34}$ Al-Ṭurtūshi thus appears as a spokesman for the Sunnī community. A few years later in 520/1126, in his seventies, he died in Alexandria.

Al-Ṭurtūshì's influence on the Sunnī, and especially the Mālikī, community of Alexandria was considerable. Indeed, he helped reorganize and rejuvenate the Mâlikī intelligentsia of the whole country. Ibn Khaldūn credits him with assisting the revival of Mālikism in Egypt. He says, «in the sixth [twelfth] century (sic), Abū Bakr al-Ṭurtūshī traveled from al-Andalus (to the East). He stopped and settled in Jerusalem. The Egyptians and Alexandrians studied with him and took over from him elements of the Andalusī school (madhhab, i. e.,

${ }^{30}$ E. g., Ibn al-Abbār, al-Takmila li-kitảb al-Sila, ed. 'Izzat al-'Ațār al-Ḥusain̄̄, Cairo, 1956, vol. 2, 491. On leading Andalusis who studied with al-Ṭurtūshī in Egypt, see Lagardère, V., "L'unificateur du Malikisme oriental et occidental à Alexandrie: Abū Bakr ạt-Țurtū̌s̄ìn, ROMM, 31 (1981), 47-61.

${ }^{31}$ Ibn Farḥūn, al-Dibäj, 277.

${ }^{32}$ Leiser, «Restoration", 119-122.

${ }^{33}$ See al-Shayyāl's analysis of it, $A$ 'lām, 87-93. It must have received wide circulation, for Ibn Khaldūn critically comments on it in his Muqaddima, see Rosenthal, F., trans. The Muqaddimah, New York, 1958, vol. 2, 87.

${ }^{34}$ Itti' $\bar{a} \bar{z}$, vol. $3,88-92$. 
the Mālikism of al-Andalus) into their own Egyptian school. One of his most important followers was the jurist Sanad, the author of the Tiräz and his companions. A number of people studied with them. They included the 'Awf family and their followers". ${ }^{35}$

Al-Ṭurtūshī taught for almost thirty years and therefore had hundreds of students. The most famous were his friend al-Sadafi, who may have visited him in Egypt and later became a great judge and traditionist in al-Andalus, ${ }^{36} \mathrm{Abū} \mathrm{Bakr}$ b. al-'Arabī, another Andalusī traditionist ${ }^{37}$ and Abū Țāhir b. 'Awf. He was also the teacher of Ibn Tūmart the Mahdīi ${ }^{38}$ and gave an ijāza to the celebrated Mālikī jurist and biographer al-Qāḍī 'Iyād from Ceuta, across the straits from Gibraltar. ${ }^{39}$ The renowned al-Ghazzālī went to Alexandria when al-Ṭurtūshī was there and they surely met, although al-Ṭurtūshī was not pleased with al-Ghazzālī's Ihyā', 'ulüm al-dīn and wrote a criticism of it. ${ }^{40}$

After al-Turtushīi, the earliest reference to a madrasa in Egypt concerns that of the Mālikī judge of Alexandria al-Makīn b. Hadīd (d. 529/1135), whose family apparently arrived from Toledo in the late fifth/eleventh century.$^{41} \mathrm{He}$ may well have established it in reaction to the popularity of al-Țurtūshī and his dār/ madrasa, that is, because of professional jealousy. As the chief Mālikī official in Alexandria, he could not have been pleased to see numerous members of his madhhab flock to this Andalusī and needed a means to help retain his patronage over his community. As far as we know, it remained in the hands of the Banū Hadīd into the seventh/thirteenth century. ${ }^{42}$

\footnotetext{
${ }^{35}$ Muqaddimah, Rosenthal trans., vol. 3, 17-18.

${ }^{36}$ Ibn Bashkuwā, Kitab al-Sila, Cairo, 1966, vol. 1, 144-146; al-Dabbī, Bughya, 269; Ben Cheneb, «Étude sur les personnages", 307-309.

${ }^{37}$ J. Robson, «Ibn al-'Arabī̄, $E I^{2}$.

${ }^{38}$ Ibn Khallikān, Wafayăt, vol. 5, 46; J. F. P. Hopkins, «Ibn Tūmart", $E I^{2}$.

${ }^{39}$ Ben Cheneb, «Étude sur les personnages", 336.

${ }^{40}$ Al-Subkī, Tabaqāt, vol. 6, 242, 252; al-Murtaḍā al-Zabīiñ, Ithâf al-sāda al-muttaqūn bi-sharh asrār Ihyā 'ulūm al-dūn, 1893, rpt. Beirut, 1973, vol. 1, 28-29; Schreiner, M., «Beiträge zur Geschichte der theologischen Bewegungen im Islam", ZDMG, 52 (1898), 502, n. 7; al-Shayyāl, A'läm, 82-86.

${ }^{41}$ Mentioned in passing in S. Abd al Aziz Salem, «D'Alexandrie à Almeria, une famille alexandrine au moyen age: les Banu Khulayf, ROMM, 46 (1987), 65.

${ }^{42} \mathrm{On}$ this madrasa and its teachers, see Leiser, "Restoration», 126-130. The only reference, rather vague, to an earlier madrasa in Egypt, again in Alexandria, is to the Shāfi'i madrasa of the «Maqādisa” (Jerusalemites), which may have existed before 514/1120-1121. See ibid., 130-131.
} 


\section{MUSLIMS FROM AL-ANDALUS IN THE MADRASAS OF FĀṬIMID EGYPT}

The first full-fledged madrasa in Egypt about which we are well informed was established by Riḍwān b. al-Walakhshī , the first Sunnī vizier of the Fātimids in the sixth/twelfth century. ${ }^{43}$ It was built in Alexandria for the Mālikīs in 532/1137-1138 and was commonly known as the 'Awfiyya after its most outstanding mudarris al-Imām Șadr al-Dīn, or Șadr al-Islām, Abū Ṭāhir Ismā‘̄il b. 'Awf al-Zuhrī al-Iskandarī. Born to a family of prominent jurists, he held his teaching post in this college from the time it opened until his death in 581/1185, almost fifty years. ${ }^{44}$

As mentioned, Ibn 'Awf was a student of al-Turtūshī. In fact, he became alTurtūshī's foster son. Furthermore, it seems that al-Tiurtūshī's wife was his maternal aunt. Consequently, there was a strong alliance between the 'Awf family and the Andalusī.

After al-Ṭurtūshī died, Ibn 'Awf emerged as the leading Mālikī scholar in Alexandria. Indeed, he became the most famous Mālikī of Egypt in the sixth/ twelfth century. Even the renowned Andalusī traveler Ibn Jubair singled him out late in that century ${ }^{45} \mathrm{Ibn}$ 'Awf's longevity certainly contributed to his far-ranging reputation. References to him in the sources, especially in the general or Mâlikī biographical texts are legion. As with al-T urtūshī, a large number of Andalusīs sought him out. ${ }^{46}$ After Saladin seized power and established the Aiyūbid dynasty, even he and his sons, although they were Shāfi 'īs, attended one of Ibn 'Awf's classes. Al-Qādī al-Fāḍil, Saladin's famous counsellor and secretary, praised the sultan for going to this class and compared this to Hārūn al-Rashīd's visit, with his sons, to hear Mālik himself. ${ }^{47}$ Henceforth, whenever Saladin needed the Mālikī opinion in legal matters, he referred to Ibn 'Awf. ${ }^{48}$ Saladin's brother alMalik al-'Ādil, who was sultan from 596/1200 to 615/1218, studied hadīth with him $^{49}$ as did Saladin's nephew al-Malik al-Muzaffar Taqī 'l-Dīn 'Umar b.

\footnotetext{
${ }^{43}$ Described in detail in ibid., 131-150. The document ordering the construction of this college has survived and is translated in ibid., 435-438.

${ }^{44}$ The primary biographical sources for Ibn 'Awf are Ibn Farhūn, al-D ıbajj, 95-96, and al-Dhahabī, Ta'rikh al-Isläm, Dār al-Kutub MS. 42, ta'nkhh, vol. 27, fol. $2 \mathrm{~b}$.

${ }^{45}$ Rihla, ed. W. Wright, London, 1907, 80.

${ }^{46}$ See, e. g., Ibn al-Abbār, al-Takmila, vol. 1, 118.

${ }^{47}$ Abū Shāma, Kitāb al-Rawḍatain, ed. Muḥammad Hịilmy Aḥmad, Cairo, 1956, vol. 1, pt., 2, 24.

${ }^{48}$ See, e. g., al-Subkī, Tabaqāt, vol. 6, 41-42.

${ }^{49}$ Al-Mundhirī, al-Takmila li-Wafayāt al-naqala, first four vols. ed. Bashshār 'Awwād Ma'rūf, Najaf, 1388-1391/1968-1971, vol. 4, 326-327; al-Maqrīzī, al-Sulük, eds. M. Ziyāda and Sa 'īd 'Abd alFattāh 'Ashūr (1941-1972), vol. 1, pt. 1, 191.
} 
Shāhinshāh (d. 587/1191). ${ }^{50}$ The latter ruled Egypt for a short time during Saladin's absence and later became ruler of Ḩamāt. Ibn Mujāwir (d. 600/1204), who was a vizier of al-Malik al-'Azizz, and Ibn Shukr, who was a vizier of both alMalik al-'Ādil and al-Malik al-Kāmil, also studied hadīth from him..$^{52}$ Many others who acquired government positions studied with him as well.

Although Ibn 'Awf had many students from the Muslim West, I have only discovered one who was associated with a madrasa. This was 'Abd Allāh b. Ibrāhīm b. Sa'īd b. al-Qā'id who was born in North Africa around 551/11561157. After studying hadī $h$ with Ibn 'Awf, he became the drill master, or $m u$ ' $\bar{i} d$, of the Mālikī madrasa, the Qamhiyya, that Saladin built next to the Mosque of 'Amr in Fuștạt. He later continued hadīth studies with the Andalusī Abū Muhammad al-Qāsim al-Shātibī, whom we shall meet below, and eventually became the judge of Alexandria. He died in 645/1247. ${ }^{53}$

The 'Awfiyya remained in the hands of the Banū 'Awf throughout the Aiyūbid period. It is worthy of note that one of Ibn 'Awf's sons, Abū 'l-Ḥaram Makkī (d. 590/1194), who had an ijäza from al-Turtūshī, composed an immense work on Māliki law known as the 'Awfiyya. It was based on the fiqh lessons that he gave in his father's madrasa. It was so highly prized that a special copy was made for the library of the "Sultan of Fez". ${ }^{54}$

The next madrasa to appear in Egypt was founded by another Fātimid vizier, Ibn al-Sallār. It was a Shāfi 'i 1 institution created in 546/1151, aiso in Alexandria. Originally called the 'Ādiliyya, it soon became better known as the Hâfiziyya after the title of its first and most famous teacher, Abū Țāhir al-Silafī, who was called "al-Hāâfiz (one who had memorized the Koran)". ${ }^{55} \mathrm{He}$ was born around $475 / 1082$ in Isfahan and as a young man began to study hadith. This pursuit took him to Baghdad where he studied in the Nizāmiyya with, among others, Abū Bakr alShāshī, one of the teachers of al-Tirtūshī ${ }^{56}$ After more travels in search of hadìth, he reached Alexandria in 511/1118. Like al-Ṭurtūshī, whom he met, he married a woman of means and thus settled in that city. For the next thirty years

${ }^{50}$ Al-Mundhirī, al-Takmila, vol. 1, 292-293; al-Subkī, Țabaqāt, vol. 7, 242.

${ }^{51}$ Al-Mundhiri, al-Takmila, vol. 3, 41-42.

${ }^{52}$ Ibid., al-Maktaba al-Baladiyya (Alexandria), MS. 1982, dal, fols. 115b-116a; Ibn Farhūn, alDibajj, 43; al-Maqrīīi, al-Suluk, vol. 1, pt. 1, 219, and al-Khitat, vol. 2, 371-373.

${ }^{53}$ Al-Husaini, Silat al-Takmila li-Wafayāt al-naqala, Köprülu Mehmet Pașa MS 1101, fols. 42b43a; al-Dhahabī, Ta'rkh, Ahmet III MS. 2917, vol. 17, fols. 255a and b.

${ }^{54}$ Al-Mundhirī, al-Takmila, vol. 1, 387; al-Dhahabī, Ta'rikh, Dār al-Kutub MS. 42, ta'rikh, vol. 27, fols. 55b-56a; Ibn Farhūn, al-D ibäj, 95-96; GAL, Supplement, vol. 2, 960, nt. 21.

${ }^{55}$ The fundamental study of al-Silafi is Sher M. Zaman, «Abū Țăhir Ahmad b. Muhammad al-Silafi al-Ișbahānī, His Life and Works, with an Analytical Study of His Mu'jam al-Safar, Dissertation, Harvard, 1968. See also Leiser, «Restoration», 151-184; Cl. Gilliot, «al-Silafī», $E I^{2}$.

${ }^{56}$ Ibn Khallikān, Wafayāt, vol. 1, 105; al-Subkī, Tabaqāt, vol. 6, 36. 
he devoted himself chiefly to teaching hadīth. He attracted countless students and corresponded with scholars as far away as al-Andalus. ${ }^{57}$ His fame in hadìth eventually brought him to the attention of Ibn al-Sallār.

An overwhelming success as a teacher, al-Silafī died in 576/1180 after teaching in Egypt for almost sixty years, twenty-two of them in his madrasa. He had many of the same students as al-Turtūshī and Ibn 'Awf, including dozens from al-Andalus. One of the most noteworthy of these students was $A b \bar{u}$ Muḥammad Jāmi ' b. Bāqī al-Tamīmī. He traveled from his homeland to Egypt where he met al-Silafi and eventually became the qāad $\bar{\imath}$ of Ikhmìm in Upper Egypt. ${ }^{58}$ Another was Sābiq al-Dīn Abū Bakr Yahyā b. Sa'dūn b. Tamām b. Muhammad al-Azdī al-Qurtubī. Born in Cordova in 486/1093, he studied hadī th with al-Silafí and went to Baghdad and finally Mawșil where he settled and became known as a grammarian. ${ }^{59}$ One generation removed from al-Andalus was Abū Muḥammad 'Abd Allāh b. 'Abd al-Jabbār b. 'Abd Allāh al-Qurashī alUmawī al-'Uthmānī (d. 614/1218). He was born in Alexandria and studied ha$d \bar{t} h$ from al-Silafi. He later taught that subject in Fustật, Qūs in Upper Egypt, and even Yemen, but was by profession a cloth merchant and member of the Kārimī merchants who where involved in the trade between Egypt and India. ${ }^{60}$

As a mudarris in a madrasa, al-Silafî's main purpose was to teach figh. In addition to hadīth, he did indeed teach not only Shāfi'i law but also comparative law or khiläf. For the latter, he used Ibn 'Abd al-Barr's Kitäb al-Istidhkär, which was a commentary on the Muwatta' of Mālik. In a manuscript fragment that has survived, he states that he had never seen a book more worthy of lecturing on than the Muwatta' and that he began lecturing on it twice a week in 551/1156-1157 ${ }^{61}$ He adds that he subsequently became the subject of controversy and so he decided

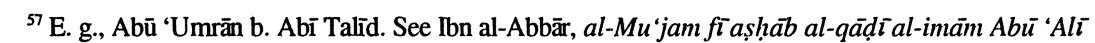
al-Șadafi, Cairo, 1387/1967, 48.

${ }^{58}$ Al-Subkī, Tabaqāt, vol. 8, 137.

${ }^{59}$ Yãqūt, Irshād al-arīb, ed. D. S. Margoliouth, London, 1907-1926, vol. 7, 278-279; Ibn alQifțī, Inbāh, vol. 4, 38-39; Ibn Khallikān, Wafayāt, vol. 6, 171-173; al-Dhahabī, Ta'rīkh, Ahmet III MS. 2917, vol. 14, fol. 16b-17a.

${ }^{60}$ Al-Mundhirī, al-Takmila, vol. 4, 305-306; al-Dhahabī, Ta'rikh, Dār al-Kutub MS. 42 ta'rikh, vol. 30, fol. $210 \mathrm{~b}$.

${ }^{61}$ The manuscript is al-Silafi's introduction to his lecture on Kitäb al-Istidhkär. It has been edited in Leiser, «Restoration", 444-470. In this lecture, al-Silafi also gives a brief description of the difference in technical terms used in $i j \bar{z} z a s$ and $s a m \bar{a}^{-} s$ (certificates of audition) between al-Andalus and the East and how to determine their validity (fols. 119a-b). He also tells us that he studied in Alexandria such

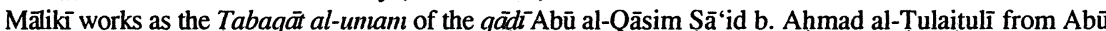
Muhammad 'Abd Allāh b. Muḥammad al-Yaḥsubī al-Andalusī (fol. 120a). On the latter, see Ibn alAbbār, al-Taknila, vol. 2, 818. The Andalusīs from whom al-Silafĩ studied in Alexandria are found in Insān 'Abbās, ed. Akhbār wa taräjim andalusiyya, Beirut, 1963, which is extracted from al-Silafî's Mu'jam al-safar. 
to base his lectures on Ibn 'Abd al-Barr's commentary on the Muwatta'. He also cites on this matter the remarks of a correspondent of his in al-Andalus, which was Ibn 'Abd al-Barr's homeland. These lectures, in addition to those on hadīth, would have made him doubly attractive, of course, to students of Mālikì law. One of al-Silafî̀'s assistants in his madrasa was probably the Andalusī Abū Isḥāq Ibrāhīm b. 'Abd Allāh al-Anșārī al-Balansī (d. 590/1193-1194), a traditionist who taught in Valencia before going to Alexandria. He stayed in al-Silafi's madrasa for twenty years. He was an ascetic, although not described as a Șūfí, and used this college as a refuge from the world. ${ }^{62}$

The students of al-Silafi who were trained in hadīth became collectively known as "the disciples of al-Silafi" ( $a$ șhäb al-Silafi $)$. They carried his name and teaching throughout much of the Islamic heartland. The man described as the last living member of the așhăb was the Māiliki Abū Bakr Muhammad b. al-Ḥasan alTamīmī al-Safāqusī. His father's family came from Sfax in North Africa. Abū Bakr was born in Alexandria in 572/1176-1177 and, though little more than a baby, attended al-Silafi's courses. He went on to become $n a^{\prime \prime} i b$ al-hakm (vicegerent) in Alexandria and died in 654/1256. ${ }^{63}$

Colleges of law first took root and flourished therefore in Alexandria where they served chiefly the Mālikīs. The Mālikī madrasas of that city were, in fact, probably the first of that school to be established anywhere in the Muslim world. Next to appear there were Shăfi 'i colleges. The other madhhhabs were of no consequence, hence they had no such institutions. Relations between the Mālikīs and Shāfi 'îs were cordial and attending each other's madrasas for subjects other than figh was commonplace. In the last seventy years of the Fạtimid Caliphate, these two madhhabs were, judging from the evidence at hand, well organized, vigorous, and generally unhindered.$^{64}$

The outstanding teachers of these years, apart from al-Turtūshī, were the friends Ibn 'Awf and al-Silafi. They both had hundreds of students and made Alexandria a major center of Sunnī —Mālikī and Shāfi 'ī_education.

${ }^{62}$ Al-Dabbī, Bughya, 219-222.

${ }^{63}$ Al-Ṣafadī, al-Wäfí, Ahmet III MS. 2920, vol. 26, fols. 92b-93a.

${ }^{64}$ Andrew Ehrenkreutz' statement that Ibn al-Sallär «antagonized the Shiites by reestablishing officially a Sunni juridical school (madrasa) of the Shafite rite in Cairon, Saladin, Albany, New York, 1972, 14, requires qualification apart from his oversight of mentioning Cairo instead of Alexandria. He cites Ḥasan Ibrāhīm Ḥasan's Ta'ríkh al-dawla al-fătimiyya, 184, where that author says, "By this means Ibn al-Sallār prepared the way for the return of the Sunnī madhhab to Egypto, which is mistaken. Ira Lapidus' assertion that when Saladin came to power the madhhabs "scarcely existed" and that he tried to urecapitulate centuries of school (madhhab) development" cannot be maintained, «Ayyūbid Religious Policy and the Development of the Schools of Law in Cairom, in Colloque International sur l'histoire de Caire, Köln, Böhlau, 1974, 281-282. 


\section{MUSLIMS FROM AL-ANDALUS IN SALADIN'S MADRASAS IN EGYPT}

In 567/1171 Saladin suppressed the moribund Fạ̄timid Caliphate in Egypt and founded the Aiyūbid dynasty. The end of this Shī' $\overline{1}$ caliphate and the official return of Egypt to the Sunnī fold had a number of consequences for the religious life of that country. Among them, the number of madrasas, above all for the Mālikī and Shāfi 'i i schools of law, increased dramatically. And these institutions played a major role in the restoration of Sunnism. I have found reference to at least 48 colleges built in Egypt during the time of the Aiyūbid dynasty: 23 for the Shāfi 'īs, 11 for the Mālikīs, two for both the Shāfi 'īs and Mālikīs, five for the Hanafiss, one for the Shāfi 'īs and Hanafīs, one for the Shāfi 'īs, Mālikīs, Hanafīs and Hanbalīs, and five of undetermined affiliation. Among these colleges, four were built in Alexandria, 14 in Fustāt, and 17 in Cairo. ${ }^{65}$ With very few exceptions, each madrasa had one professorship which, in principle but not always in practice, was held for life. As Shāfi 'îs, Saladin and his family did much to encourage the emigration of Shāfi 'i religious scholars from the Muslim East to Egypt. ${ }^{66}$ This helps explain the large increase in the number of their colleges. The Aiyūbids made no attempt, however, to encourage the emigration of Mālikī scholars from the West, that is, al-Andalus and North Africa, which were almost exclusively Mālikī. Nevertheless, because of the long and continuous tradition of the rihla, this was not necessary. In what follows, we shall focus on the Maghribis who were associated with some of these new Mālikī, and a few other, madrasas and reveal their continuing presence in these institutions in Egypt.

We know that Saladin built at least five madrasas in Egypt: two in Fustạt (the Nāṣiriyya for the Shāfi 'īs and the Qamhiyya for the Mālikīs), one in Cairo (the Suyüfiyya for the Hianafis), one in the nearby Qarāfa Cemetery (the Șalāhiyya for the Shäfi ('is), and one in Alexandria. We have substantial information on the first four, but the one in Alexandria is much of a mystery. With each of the others, the sultan took great care in choosing its site and provided it with a handsome endowment. In fact, these four colleges emerged as the wealthiest and most prestigious in the country throughout the Aiyūbid period. Although Saladin was a Shāfi ' $'$, he clearly took account of all the leading Sunnī madhhabs except the Hanbalīs, who continued to be of little significance in Egypt. Thus, one of his madrasas in Fustật was for the Mālikīs and the one in Cairo was for the Hanafís, their first college in Egypt. The sultan more or less hand-picked their professors. Their lines of succession, however, are difficult to determine.

\footnotetext{
${ }^{65}$ See Appendix V in Leiser, «Restoration", 471-472.

${ }^{66}$ This was shown in Leiser, «Restoration".
} 
Saladin's Māiliki madrasa, the Qamhiyya (from qamh, wheat, a reference to the crop of its endowed village), was built near the Mosque of 'Amr in 566/ 1170.67 Among the professors of this college was Kamāl al-Dīn Abū 'l- 'Abbās Ahmad b. 'Alī al-Qastallānī. His family was originally from North Africa but he was born in Egypt in 559/1163-1164. He studied Malikī law with his uncle, a $q \bar{a} \bar{d} \bar{l}$, and was initiated into Șūfism. He also had an ijāza from al-Silafî. He became a mudarris in the Qamhiyya but later left it to go wandering about Mecca in the pursuit of further study and died there in 636/1239. ${ }^{68}$ His son Tāj al-Dīn Abū 'l-Ḥasan 'Alī also taught in this madrasa. He was born in Egypt in 588/1192 and later taught hadīth and was a mufti (one who gave legal opinions) before becoming the professor. Later he was appointed to the chair of the Dār al-Hadith al-Kāmiliyya, which was an institution for teaching tradition, where he remained until his death in 665/1267. ${ }^{69}$ His brother, Qutb al-Dīn Muhammad, became a Shāfi î and also held the teaching chair in the Kämiliyya, probably succeeding Tāj al-Dīn. He died in 686/1287. ${ }^{70}$

I have discovered only one teaching assistant for the Qamhiyya, Abū Muḥammad 'Abd Allāh b. Ibrāhīm al-Hilāì al-Rỉghī. He was a Malikī from what is today Algeria. He was born there around 551/1156-1157. Al-Silafi sent him an ijaza and he eventually went to Alexandria and studied hadīth from Ibn 'Awf. Afterwards, he went to Fustạat to pursue the same subject with Abū Muhammad al-Qāsim al-Shạtibī and serve as the $m u$ ' $\bar{l} d$ in the Qamhiyya. He returned to Alexandria and became its chief $q \bar{a} d \bar{l} \bar{l}$ in 603/1206-1207. He also became the $k h a t i b$ (the one who gave the Friday sermon) of that city. He held both posts for some forty years, retiring a few years before his death in 645/1247. ${ }^{71}$

Saladin founded his madrasa for the Hanafis in Cairo in 572/1176-1177. Because it was next to the market of the sword makers (suyujf, swords), it was called the Suyüfiyya. It was a short distance from the former Fātimid palace. ${ }^{72}$ Its first professor was Majd al-Dīn Abū 'Abd Allāh Muhammad b. Muḥammad al-

${ }^{67}$ On this madrasa and its teachers, see ibid., 201-211.

${ }^{68}$ Al-Mundhirī, al-Takmila, al-Maktaba al-Baladiyya MS. $1982 \mathrm{dal}, 238$; al-Dhahabī, Ta'rikh, Ahmet III MS. 2917, vol. 17, fol. 119a; al-Șafadī, al-Wäfī, vol. 7, 238; Ibn Farḥūn, al-D ibāj, 67.

${ }^{69} \mathrm{Al}-\mathrm{Dimyātāi,} \mathrm{Mu'jam} \mathrm{al-shuyūkh,} \mathrm{ed.} \mathrm{G.} \mathrm{Vajda} \mathrm{as} \mathrm{Le} \mathrm{Dicṫionnaire} \mathrm{des} \mathrm{autorités,} \mathrm{Paris,} 1962$, 71; al-Yunīnī, Dhail Mir'āt al-zamān, Hyderabad, Deckan, 1374-1380/1954-1961, vol. 2, 371-372; al-Dhahabī, Ta'rīkh, Ahmet III MS. 2917, vol. 18, fol. 238b, and idem,'al-'Ibar fï khabar man ghabar, eds. Şalāḥ al-Dìn al-Munajjid and Fu'ād Saiyid, Cairo, 1960-1966, vol. 5, 281; al-Tinbuktī, Nail al-ibtihāj, published on the margins of Ibn\Farhūn, $a l-D \bar{\imath} b \bar{a} j, 63$.

${ }^{70}$ Al-Dimyậ̣̂̄, Mu jam, 113; al-Ṣafadì, al-Wäfī, vol. 2, 132-135. Cf. Ibn Shākir al-Kutubī, Fawät al-Wafayāt, ed. Ihsān 'Abbās, Beirut, 1973-1974, vol. 3, 310-312; ‘al-Subkī, Tabagāt, vol. 8, 43-44.

${ }^{71}$ Al-Dhahabī, Ta'rzkh, Ahmet III MS. 2917, vol. 17, fol. 255a and b; al-Maqrīz̄, al-Muqaffä, Paris MS. arabe 2144, fol. 179a.

${ }^{72}$ On this madrasa and its teachers, see Leiser, «Restoration», 211-225. 
Khutanī, a scholar from Central Asia. His nisba (noun of relation, geographical nomenclature) derived from the city of Khutan (Khotan). After studying hadìth and figh in Transoxiana and Khurāsān, he went to Iraq and then Damascus where he fought against the Crusaders and Nūr al-Dīn appointed him to the Șādiriyya Madrasa. He later left to make the pilgrimage and then continued to Egypt where Saladin appointed him to the Suyunfiyya. His connection with al-Andalus was that he departed for that country - a rare occurrence for an Easterner- and asked Abū 'l-Qāsim al-Shạtibī to go with him. He then returned to the Suyūfiyya and resumed teaching until his death in 586/1 $190 .{ }^{73}$ One of his acquaintances in Egypt was the Andalusī Muhammad b. Țāhir al-Khidabb who went to Cairo on the way to Mecca. Al-Khutanī lodged him in the Suyūfiyya and he came to know al-Qăḍ̂̄ al-Fādị and had access to al-Fādili's famous library. Al-Khutanī again befriended him on his return from the pilgrimage. It seems that he was traveling with a slave girl and when they reached the boat on the Nile that was to take them downstream, she was smitten by a young soldier whom she met on the boat. She then stole all of her master's gold (din̄ärs) and gave them to the soldier. Al-Khutani helped him get his money back and prepared him for his return to al-Andalus. He died around 570/1174-1175 while on the way. ${ }^{74}$

In 575/1180 Saladin founded the Șalāhiyya Madrasa for the Shāfi 'îs in the Qarāfa Cemetery. It was his last major college and the most prestigious in Egypt throughout the Aiyübid period. ${ }^{75}$ Its prestige derived above all from its location next to the tomb of al-Shāfi ${ }^{\top}$ himself and the exceptionally high salary paid to its mudarris. The first to hold its professorship was Najm al-Dīn Abū 'l-Barakāt Muhammad b. al-Muwaffaq al-Khabūshānī, a conceited and pugnacious man from Khurāsān who had a tumultuous career in Egypt from the day he arrived in $565 / 1169-1170$ until his death there in 587/1191. ${ }^{76}$ His reputation was such that Ibn Jubair had even heard of him in al-Andalus and later visited him in his masjid

${ }^{73} \mathrm{Al}$-Fìrūzābādī, al-Mirqāt al-wafiyya fì tabaqāt al-hanafiyya, Dār al-Kutub MS. 4647 ta' rïkh, fols. 73b-74a; Ibn Abī 'l-Wafā', al-Jawähir al-mudī a fi tabaqät al-hanafiyya, Hyderabad, Deccan, 1332/1914, vol. 2, 125-126, who says he died in 576; Taqi ' 'l-Dīn al-Tamìmì al-Ghazzī, Tabaqāt alsaniyya fïtaräjim al-hanafiyya, Süleymaniye MS. 829, fols. 443a and b; 'Alī b. Muhammad al-Harawī, al-Athmār al-janiyya fì asmä' al-ḩanafiyya, Şehid Ali Paşa MS. 1841, fols. 75b-76a; Yāqūt, Mu 'jam al-buldān, vol. 2, 403; al-Nu'aimī, al-Dāris fĭ ta'r rikh al-madāris, ed. Ja 'far al-Ḥasan̄̄, Damascus, 1367-1370/1948-1951, vol. 1, 539.

${ }^{74} \mathrm{Ibn}$ al Qiftū, Inbahh, vol. 4, 188-189, where our shaikh is called al-Khanathī; al-Suyūtū, Bughyat al-wu 'ät fì tabaqāt al-lughawiyyīn wa 'l-nuhāat, ed. Muḥammad Abū 'l-Fạ̣l Ibrāhīm, Cairo, 19641965 , vol. 1, 28.

${ }^{75}$ On this madrasa and its teachers, see Leiser, «Restoration", 225-262.

${ }^{76}$ On his life, see ibid., 233-249, and idem, «The Madrasa and the Islamization of the Middle East: The Case of Egypt", JARCE, 22 (1985), 42-43. 
in Cairo. ${ }^{77}$ There is very strong evidence that al-Khabūshānī was the first to recite the khutba (Friday sermon) in Egypt in the name of the "Abbāsid caliph and thus officially signal the end of the Fạtimid Caliphate. It is worthy of note, however, that according to Ibn al-Abbār (d. 658/1260) the first to do this was one al-Yasa " b. 'Īsā b. Ḥazm al-Ghāfiqī al-Andalusī. He supposedly went to the minbar (pulpit, which one?) with a contingent of soldiers, swords flashing as a precaution against a potentially violent $S^{i}{ }^{i} \bar{i}$ reaction, and delivered the $k h u t b a .^{78}$

It should be mentioned here that the most famous woman traditionist during this period was Fătima bint $\mathrm{Sa}$ 'd al-Khair, who was a generation removed from al-Andalus. Her Hianbalī husband, 'Alī b. Ibrāhīm b. Najā, was one of the signers of the waqf (endowment) of the Suyūfiyya and at one point had warned Saladin of an impending pro-Fātimid coup. He was also an enemy of al-Khabūshānī. As for Fātima, she was born in Isfahan in 522/1128. Her father Sa'd al-Khair b. Muhammad b. Sahl al-Maghribī al-Andalusī al-Anșārī had set out from alAndalus for China. He reached his destination after many hardships and was given the additional nisba of al-Șinī. He studied figh from al-Ghazzālī and tradition from others in Baghdad on the way. When he returned from China, he studied hadìth in Isfahan where he was married and Fātima was born. He then settled in Baghdad and died there in 541/1 $146 .^{79}$. Sa $\mathrm{d}$ al-Khair made his daughter study under many notable teachers in Isfahan and Baghdad and she acquired ijozzas from dozens of other scholars. Although her husband was a Hanbalī, and one of her father's students, she was apparently a Shāfi'ī. She and 'Alī later went to Damascus to teach tradition. Just before Saladin abolished the Fătimid Caliphate, they arrived in Egypt where they spent the rest of their lives. In Cairo, Fạtima attracted a large following. Among her students were the son of al-Qādī al-Fādilil, and muqri's (teachers of Koran recitation) in the Fādililiyya (see below) and Fakhriyya ${ }^{80}$ madrasas and professors in the Suyūfiyya and Nāșiriyya madrasas. She died in 600/1203. ${ }^{81}$

Al-Maqrīzī tells us that Saladin established a märistān (hospital) a «dār for the Maghribīs", and a madrasa at the tomb of his brother Tūrānshāh in Alexandria

${ }^{77}$ Rihla, 22-23.

${ }^{78} \mathrm{Al-Mu}$ 'jam, 334-336; al-Maqqarī, Nafh, vol. 1, 713. Ibn al-Abbār's authority here was one of his teachers, Muhammad b. 'Abd al-Malik al-Tujīîi who claimed to have been told this by al-Andalusī himself in Egypt.

${ }^{79}$ Ibn al-Jawzī, al-Muntazam, Hyderabad, Decca, 1357-1358/1938-1940, vol. 10, 121; al-Subkī, Tabaqät, vol. 7, 90 .

${ }^{80}$ On this madrasa, which was founded in Cairo in $622 / 1225$ for the Shāfi 'îs and Ḥanafîs, and its teachers, see Leiser, «Restoration», 349-352.

${ }^{81}$ Al-Mundhiri, al-Takmila, vol. 3, 111-116; 'Umar Riḍā Kaḥhāāa, A 'lām al-nisä’', Damascus, 1959, vol. 4, 59-60, who says she was born in Bahrain. Cf. al-Subkī, Ṭabaqāt, vol. 7, 90. 
in 577/1181-1182 when he went to that city and attended Ibn 'Awf's lectures. ${ }^{82}$ No other information has come to light on any of these institutions.

\section{MUSLIMS FROM AL-ANDALUS IN THE OTHER MADRASAS OF THE AIYŨBID PERIOD}

After Saladin's Qamhiyya Madrasa, the second most important Mālikī madrasa was the Șāhibiyya founded in Cairo by the vizier al-Șahạib Șafî 'l-Dīn 'Abd Allāh b. 'Alī b. Shukr (d. 622/1225) sometime between 596/1200 and 611/ 1214-1215. ${ }^{83}$ As mentioned, he had studied hadīth from Ibn 'Awf and al-Silafi. He also studied Malikī fiqh from one Abū Bakr 'Atīq al-Bijā'̀ , from Bijāya in North Africa.

There were surprisingly few Maghribīs associated with this college. AlMundhirī provides a brief notice of a man who was the imām of the Șanhibiyya. This was Abū Rabī' Sulaimān b. 'Abd Allāh b. Yūsuf al-Hawwārī al-Jalūlì (d. 612/1215). Chiefly known as a muqri', he may have taught qirä'a (Koran recitation) in this madrasa. His nisbas refer to places in North Africa. ${ }^{84}$

In 580/1184, al-Qāại al-Fāḍil established a madrasa for the Mālikīs and Shāfi 'is in Cairo. ${ }^{85}$ As mentioned, he had studied tradition from Ibn 'Awf and alSilafi. The Fādiliyya was especially known for qirä'a. Its first muqri' and imäm was the famous Abū Muhammad al-Qāsim b. Firrūh al-Ru'ainī al-Shătibī who overshadowed the first mudarris of this institution. ${ }^{86}$ His nisbas indicate that he traced his descent from the Ru'ain tribe in Yemen and that he was from Játiva in al-Andalus. He was born in that city in 538/1144. He studied qirä' $a$ there and became its khat $\bar{l} b$ while still a youth. Later he moved to Valencia where he studied the same subject as well as hadith. In 572/1176-1177 he arrived in Alexandria where he studied tradition from al-Silafi. He then went to Cairo where al-Qāọī al-Fāḍil welcomed him. After al-Fāḍil completed his madrasa, he appointed al-Shătibī as muqri'. Al-Shătibī also made the pilgrimage and visited Saladin in Jerusalem in 589/1193. He died in 590/1194 and was buried in alFāḍil's grave plot in the Qarāfa Cemetery. An authority on Mālikī law, Arabic, grammar, tafsìr (Koranic exegesis), hadīth and even the interpretation of dreams, he was without peer in qirä’a, a subject in which he was described as the "top man

${ }^{82}$ Al-Sulük, vol. 1, pt. 1, 76.

${ }^{83}$ On this madrasa and its teachers, see Leiser, «Restoration", 317-327.

${ }^{84}$ Al-Takmila, vol, 4, 176-177; al-Dhahabī, Ta'rikh, Dār al-Kutub MS. 42, ta'rikh, vol. 29, fol. $192 b$.

${ }^{85}$ On this madrasa and its teachers, see Leiser, «Restoration", 334-347.

${ }^{86}$ Al-Maqrīzī, al-Khitat, vol. 2, 366. Cf. Al-Șafadī, al-Wäfī, vol. 24, 146-148. 
in Egypt" ${ }^{87} \mathrm{He}$ was succeeded as muqri' by his student, the Mālikī Abū 'Abd Allāh Muhammad b. 'Umar al-Anșārī al-Qurtubī (d. 631/ 1233). Born in 557 or 558/1 161-1163 in Cordoba, al-Qurtubī had studied qirā'a with 'Alī b. Mūsā b. 'Alī b. Naqrāt (d. 593/1196-1197), who had visited Egypt and later became the khat $\bar{\imath} b$ of Fez, ${ }^{88}$ and Yahyā b. Muhammad b. Khalaf al-Hawzanī al-Ishbīlī (d. 602/1206), who had been a muqri' in Ceuta. ${ }^{89} \mathrm{He}$ also studied tradition from a number of scholars. He taught for some time in the Fādiliyya and then left to make the pilgrimage. He spent the rest of his life in the Hijāz and died in Medina. ${ }^{90}$

Usually included in a catalogue of the madrasas of Egypt was the Dār alHadīth al-Kāmiliyya, which, as mentioned, was a special institution for teaching hadīth, although Shāfi ${ }^{\prime} \overline{1}$ law was taught there as well. It was built in $622 / 1225$ by Sultan al-Malik al-Kāmil. No other facility like it was established during the period in question. ${ }^{91}$

The first muhaddith, or teacher of hadīth, was Majd al-Dīn Abū 'l-Khattāb 'Umar b. Dihya. He was born in Valencia around the middle of the sixth/twelfth century. He spent his early years traveling around al-Andalus studying grammar and tradition. He twice became the qādi of Denia, on the coast south of Valencia, before finally leaving for North Africa. He journeyed east, no doubt studying en route, and stopped in Tilimsān, Bijāya and Tunis. He made the pilgrimage and then continued to Syria, Iraq and Iran pursuing hadīth studies in Baghdad, Wāsit, Isfahan and Nīshābūr. He finally settled in Egypt during the reign of al-Malik al'Ādil (596-615/1200-1218) who had heard of him and encouraged him to move to Cairo. Subsequently, al-'Ādil asked him to tutor his son al-Kāmil. Later, when the latter became sultan, he built the Kāmiliyya especially for Ibn Dihyya.

Unfortunately for our shaikh, he eventually fell from favor. Many of the 'ulama' (religious scholars) accused him of being a charlatan. They charged that he had falsified his educational background and that his confusing lectures revealed that he did not know what he was talking about. At least one of them went to al-Andalus and began to inquire about him. The Andalusī shaikhs denied

${ }^{87}$ Al-Mundhirī, al-Takmila, vol. 1, 383-385; Abū Shāma, Dhail, 7; Ibn Khallikān, Wafayāt, vol. 4, 71-73; Yāqūt, $M u$ 'jam al-buldān, vol. 6, 84-85; al-Subkī, Țabaqāt, vol. 8, 270-272; al-Asnawī, Tabaqāt al-Shäfi 'iyya, ed. 'Abd Allāh al-Jabūrī, Baghdad, 1390-1391/1970-1971, vol. 2, 113-114; Ibn Farhūn, al-Dībājj, 224; Ibn Duqmāq, Tarjumān al-zamān, Ahmet III MS. 2927, vol. 13, fols. 12b-13b; Ibn al-Jazarī, Ghāyat al-nihāya fi tabaqāt al-qurrā', eds. Gotthelf Bergstrasser and Otto Pretzel, Cairo, 1932-1935, vol. 2, 20-23; al-Dāwūdī, Tabaqāt al-mufassiriñn, ed. 'Alī Muhammad 'Umar, Cairo, 1392/1972, vol. 2, 39-42; Angelika Neuwirth, «al-Shătibì', $E I^{2}$.

${ }^{88}$ Ibn al-Jazari, Ghäyat, vol. 1, 581-582.

${ }^{89}$ Ibid., vol. 1, 377-378.

${ }^{90}$ Al-Mundhir̄ī, al-Takmila, al-Maktaba al-Baladiyya MS. dāl, 140; Abū Shāma, al-Dhail, 162; Ibn al-Jazarī, Ghäyat, vol. 2, 219-220.

${ }^{91}$ On this dār al-hadüth and its teachers, see Leiser, «Restoration», 361-375. 
all of his claims including his descent. Al-Kāmil at first refused to believe the charges, but the religious scholars raised such an outcry that he gave in to their pressure and decided to test Ibn Dihya's knowledge of hadith. To his dismay, he discovered that the charges were true. Consequently, Ibn Dihya was dismissed and died shortly thereafter in $633 / 1235$. He was a Zāhirī, which may have been a factor in the opposition to him. ${ }^{92}$

He was replaced at the Kāmiliyya by his older brother Muhyī 'l-Dīn Abū 'Amr 'Uthmān. The two had apparently left al-Andalus and traveled together until settling in Cairo. Ibn Wạsil says he was in the service of the qạ̄̂̀ 'l-'askar (judge of the army) Shams al-Dīn al-Armawī and that he taught figh in Saladin's Shāfi' 1 ì Nāșiriyya Madrasa next to the Mosque of 'Amr. In spite of his relatively high standing, he too was branded an impostor and an incompetent after he became the muhaddith of the Kāmiliyya. He followed his brother to the grave in 634/1237.93

One of the next to hold the position of muhaddith was Muhyī 'l-Dīn Abū Bakr Muhammad b. Muhammad al-Anșārī al-Andalusī al-Shātibī. He was born into a family of $q \bar{a} d \bar{l} \bar{s}$ and faqìhs in Játiva in 592/1196. He was a Mālikī who studied the figh of that school in his native land and then traveled to the East in pursuit of hadith. His goal was Baghdad where he studied that subject with a number of scholars. In 626/1228-1229 he was in Irbil where he studied qirä'a. Afterwards, he went to Aleppo and took the chair of the Dār al-Hadìth alBahā'iyya. Finally, he moved to Egypt where he was appointed to the Kāmiliyya. He held that position until his death in $662 / 1263 .{ }^{94}$ According to al-Suyūtī, he was succeeded by the Mālikī, and former professor of the Qamhiyya, Tāj al-Dīn Ibn al-Qastallānī who remained there until he died in 665/1267. ${ }^{95}$

I have not discovered any other Maghribīs associated with the madrasas of Alexandria, Fustạt, or Cairo for our period. As for those in madrasas outside these

\footnotetext{
${ }^{92} \mathrm{He}$ is mentioned in many sources. See Ibn Khallikān, Wafayāt, vol. 3, 448-450; Ibn Wāșil, Mufarrij al-kurüb, Paris MS. arabe 1703, fols. 3b-4b; al-Nuwairī, Nihāyat al-arab, Dār al-Kutub MS 549 ma'rüf 'ämma, vol. 27, 51; al-Safadī, al-Wäfí , vol. 22, 451-455; Abū Shāma met him in the Kāmiliyya and says it was built in 641, al-Dhail, 142; Ibn al-Faqīh, Murshid al-zuwwār, British Museum MS. OR. 4635, fols. 281a-283b; and see the references in Bashshār Ma 'rüf, al-Mundhir 'w wa kitäbu-hu al-Takmila li-Wafayät al-naqala, Najaf, 1388/1968, 132-133; GAL, vol. 1, 310-312 and Supplement, vol. 1, 545-546; Goldziher, I., The Zähiris: Their Doctrine and Their History, trans. Wolfgang Behn, Leiden, 1971, 161-164; Hans Gottschalk, al-Malik al-Kämil von Egypten und seine Zeit, Weisbaden, 1958, 129.

${ }^{93}$ Ibn Khallikān, Wafayāt, vol. 3, 450; Ibn Wāsil, Mufarrij, Paris MS. arabe 1703, fols. 4b-5a; alDhahabī, Ta'rikh, Ahmet III MS. 2917, vol. 17, fols. 91b-92a; al-Ṣafadī, al-Wäfi $i$, vol. 19, 479. Additional references are in Ma'rūf, al-Mundhiri, 134.

${ }^{94}$ Al-Dimyậtī, Mu 'jam, 124; al-Yunīnī, Dhail, vol. 1, 304-305; al-Șafadī, al-Wäfì, vol. 1, 208; Ibn Shäkir, Fawāt, vol. 3, 245-246; Ibn Kathīr, al-Bidāya wa 'l-nihāya, Cairo, 1351-1358/1932-1934, vol 13, 243; al-Suyūtī, Hiusn, vol. 2, 262.

${ }^{95}$ Hesn, vol. 2, 262; al-Husainī, Șilat, fols. 158b-159b; al-Yunīnī, Dhail, vol. 2, 271-272.
} 
major cities, they rarely appear in the sources. One of them was the Mālikī Abū 'l-Ḥasan 'Alī b. Khalaf al-Kūmī al-Maḥmūdī al-Fatazūsī al-Tilimsānī who taught in a Shāfi '⿳亠 madrasa in Munyat Ban̄i Khașīb in Upper Egypt. From his home in North Africa, he journeyed to Egypt where he studied hadith and fiqh in Alexandria and then made the pilgrimage. After a few years in the Hijāz, he moved to Baghdad to continue his tradition studies. He then returned to Egypt and taught hadìth in Fustạạt before finally settling in Munyat Banī Khașīb where he died in 599/1203. ${ }^{96}$

An Andalusī who went to Upper Egypt was the Shāfi 'ī Najm al-Dīn Abū Naşr Fatḥ b. Mūsāa al-Umawī al-Jazīī al-Qașrī. He was born in Algeciras (al-Jazīra alKhaḍrā') in al-Andalus in 588/1192. His father took him to Qașr 'Abd al-Karīm, near Ceuta and opposite Algeciras, and when he was around five years old to Qașr Kutāma, which Yāqūt says was a city on Algeciras. Al-Qaṣrī grew up in the latter Qașr. When he was fifteen, he returned to Algeciras and studied grammar there. It was perhaps about that time or a bit later that he studied tradition from 'Īsā $b$. 'Abd al- 'Azīz al-Juzülī (d. 607/1210). ${ }^{97}$ In 609/1212-1213 he headed east. He stayed a while in Tunis and then continued to Egypt. He reached Damascus in 610/1213-1214 and studied figh and khiläf from Saif al-Dīn al-Āmidī in Ḥamāt. In 617/1220-1221 he became the professor of the madrasa of the amī 'Imād alDīn Ibn al-Mashtūu in the city of Ra's al- 'Ain between H̦arrān and Nașībīn. He held this post for many years and was placed in charge of the treasury of the eastern provinces (biläd al-sharq) under al-Kāmil. Al-Suyūtị says he also went to Baghdad and was a mudarris in the Nizāmiyya. He returned to Egypt in 643/1245 and became the professor in the Fā'iziyya Madrasa, for Shāfi 'îs, in Usyūt. He also became the $q \bar{a} \bar{d} \bar{\imath}$ of that town and died there in 663/1265. ${ }^{98}$

These then are the Muslims from al-Andalus, and a few from North Africa, who, so far, have come to light as being associated with the rise and spread of madrasas in Egypt. They were especially important in the beginning, notably in the person of al-Turtūshī, in preparing the foundation for this development. Subsequently, they appeared in teaching positions in all the leading Mālikī and a few Shāfi 'ī madrasas in Egypt until late into the seventh/thirteenth century, although in fewer and fewer numbers which reflected the decline in the rihla. Their presence, almost exclusively in Alexandria and Fustạt//Cairo, helped make

${ }^{96}$ Al-Mundhirī, al-Takmila, vol. 2, 411-412.

${ }^{97}$ On al-Juzūlī, see GAL, Supplemet, vol. 1, 541-542.

${ }^{98}$ Yãqūt, Mu'jam al-buldān, vol. 4, 119-120, on Qașr 'Abd al-Karīm 116; al-Ba 'labakkī, Dhail 'alā Mir'ât al-zamān, Aya Sofya MS. 3199, fols. 73b-74a; al-Dhahabī, Ta'rikh, Ahmet III MS. 2917, vol. 18, fols. 225a-226b; al-Subkī, Tabaqät, vol. 8, 348; al-Suyūtīi, Bughya, vol. 2, 242; Ibn alMulaqqin, al- 'Iqd al-mudhahhab fì tabaqät jumlat al-madhhab, Bodl. MS. Hunt 108, vol. 163a. 
Egypt a thriving center of Mālikī law, perhaps the most important in the Islamic world. This resulted not only from the ideas that they brought from al-Andalus but also from those acquired in the centers of learning, including madrasas, that most of them had visited in the further Islamic East. In addition, by teaching in madrasas, these Muslims also played a prominent role in the restoration of Sunnism in Egypt after the abolition of the Fătimid Caliphate. The fact that they were appointed to positions in madrasas, positions which were few and difficult to obtain, by the ruling authorities, was tantamount to official recognition of the importance of their community. ${ }^{99}$

It should be emphasized that the Andalusīs who taught in madrasas were not, of course, the only ones in Egypt. For every Andalusī who taught in a madrasa, there were many others who taught elsewhere, such as in mosques. In addition, for every Andalusī teacher, there were unquestionably dozens of Andalusī students, although most were not emigrants. Those who held positions in madrasas were, therefore, indicators of a substantial group of Andalusī religious scholars and students in Egypt. It would be reasonable to assume that without them Egypt would probably have become an overwhelmingly Shäfi 'î country. In other words, the Andalusis strengthened a conservative element that might have been lost. They also established and maintained intellectual, religious, and no doubt other, bonds between Egypt and the West that were stronger than those between the latter region and any other part of the Islamic "East". They thus helped give Egypt an intellectual and religious personality that was noticeably different from that of its eastern neighbors.

\begin{abstract}
This article describes the role of Muslims from al-Andalus in the early development and the subsequent pedagogical function of the madrasas (Islamic colleges of law) in Egypt from the late Fătimid period (495-567/1101-1171) to the end of the Aiyūbid era (567-648/1101-1250). This role is connected with the rihla, the travel of Andalusis to the Islamic East for the sake of learning. This article begins with a brief overview of the status of the law schools (madhhabs) in Egypt under the Fậtimids. This is followed by an account

\footnotetext{
why madrasas did not appear in al-Andalus itself until the eighth/fourteenth century, if at all, is especially curious. Cf. Makdisi, G., "The madrasa in Spain: Some Remarks", ROMM, 15-16 (1973), 153-158.
}

${ }^{99}$ Given the rihla and active role of Andalusīs in the Māikī madrasas of Egypt, the question of
\end{abstract}


of Andalusīs in the madrasa movement in Alexandria under Fậtimid rule and then in the spread of this institution to Fustatat, Cairo and elsewhere in Egypt under Saladin and his Aiyūbid successors. The presence of Andalusīs in all the leading Mālikī madrasas highlights their contribution to orthodoxy in general in Egypt and to its Mālikī community in particular.

\section{RESUMEN}

Este artículo describe el papel representado por los musulmanes andalusíes en el desarrollo temprano y posterior función pedagógica de las madrasas (colegios de ley islámica) en Egipto, desde el período fạtimí tardío (495-567/1101-1171) hasta el final de la época ayyūbí (567-648/1101-1250). Este papel está relacionado con la riḥla, el viaje que hacían los andalusíes a Oriente "en busca de la ciencia". El artículo se inicia con una breve exposición de la situación de las escuelas legales (madhab) en el Egipto fătimí. A esto sigue el estudio de los andalusíes que participaron en el movimiento de las madrasas en Alejandría (bajo los fạtimíes) y la difusión de esta institución en Fustạt, El Cairo y otros lugares en Egipto, bajo Saladino y sus sucesores ayyūbíes. La presencia de andalusíes en las madrasas mālikíes más importantes subraya su doble contribución, en general, a la ortodoxia en Egipto y, en particular, a la comunidad mālikí. 